\title{
OUTCOMES IN POOR RESPONDERS TREATED WITH IN VITRO FERTILIZATION/INTRACYTOPLASMIC SPERM INJECTION ACCORDING TO BOLOGNA CRITERIA
}

\section{INTRODUCTION}

Ovarian reserve has an important role in the adequate response of the ovary to ovarian stimulation and in obtaining full eggs in in vitro fertilization (IVF) programs. The ovarian reserve during the life of a woman undergoes changes. Starting from the effects of physiological factors - age-related decrease in the pool of primordial follicles to pathological conditions leading to a decrease in ovarian reserve - endometriosis, ovarian surgery and other factors [1].

Ovarian reserve is a functional reserve of the ovary, which determines its ability to develop a follicle with a full egg cell and an adequate response to ovarian stimulation. Ovarian reserve reflects the number of follicles in the ovaries (primordial pool and growing follicles) and depends on physiological and pathophysiological factors [1]. In such patients, with low ovarian response, the main problem is to obtain a sufficient number of oocytes, which reduces the rates of implantation and birth. In fact, due to the small number of oocytes received, the number of good quality embryos that are suitable for transfer decreases, and therefore the frequency of one-way pregnancy and the level of cumulative pregnancy per started cycle are reduced compared with patients with normal ovarian reserve.

Patients with a "poor ovarian responder" (POR) have mechanisms for premature ovarian insufficiency that are not fully understood to date. Some reasons for the decline in the ovarian reserve are identified: ovarian surgery, especially in the case of endometrioma [2-7], genetic defects, chemotherapy, radiation therapy, autoimmune disorders, a single ovary, chronic smoking and unexplained infertility. In addition, new risk factors for the development of "poor responders" were proposed: type I diabetes, transfusion-dependent Beta-thalassemia [8, 9] and uterine artery embolization in the treatment of uterine leiomyoma [10]. It was suggested that a reduced number of oocytes may be associated with deterioration in their quality, which is clinically transformed into a decrease in the likelihood of implantation and an increase in the rates of early pregnancy loss [11]. Conversely, due to the lack of a clear correlation between the number and quality of oocytes, various au- thors have suggested that poor responders by themselves do not represent a lesser chance of success in IVF, and the woman's age is the most important factor in the birth rate $[11,12]$. However, other studies have shown that this group of patients poor responders reduced pregnancy rates in comparison with ordinary respondents, regardless of the treatment protocol used [1215] and the patient's age [16-19]. Thus, in this group of poor responders' patients, to optimize the clinical results of IVF, it is necessary to not only predict the ovarian response, but also, in particular, adapt the best stimulation protocol in order to fully utilize the ovarian reserves and optimize the number of oocytes to be restored [19-23].

Purpose of study was to evaluate the effectiveness of various approaches of artificial reproductive technologies (ART) in advanced maternal age patients with poor ovarian response.

\section{MATERIALS AND METHODS OF THE STUDY}

This is retrospective cohort study of 455 patients with poor ovarian reserve who have undergone IVF and embryo transfer program at PERSONA International Clinical Center for Reproductive Medicine from June 2016 to June 2018.

Criteria for the inclusion of patients in the study: Bologna criteria for the definition of "poor response" [13].

Exclusion criteria: contraindications for IVF, donation of oocytes and sperm.

Figure 1 shows the characteristics of the studied groups.

Stimulation protocols were performed according to standard regimens. 36-38 hours after the ovulation trigger (human chorionic gonadotropin 5000-10000 U), transvaginal puncture was performed under the control of an ultrasound of the ovaries. Oocyte fertilization was performed using standard IVF/IntraCytoplasmic Sperm Injection (ICSI) methods, $42 \mathrm{~h}$ after trigger injection.

Embryo cultivation was carried out in culture media: Origio Sage; Incubators: Cook MINC ${ }^{\mathrm{TM}}$ Benchtop Incubator with a gas mixture as a percentage of $\mathrm{CO}_{2}-6 \%, \mathrm{~N}_{2}-89 \%, \mathrm{O}_{2}-5 \%$, at a temperature of $37.0-37.10{ }^{\circ} \mathrm{C}$. Evaluation of the quality of embryos was carried out on days 1,3 , and 5-7 on the Gardner blastocyst eval-

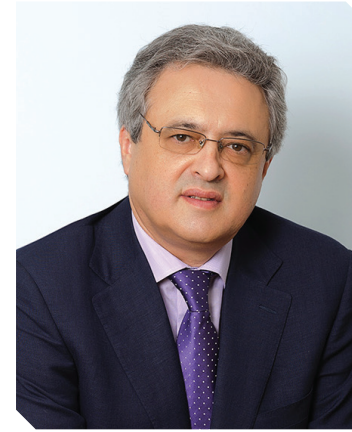

V.N. LOKSHIN

$M D, P h D$, professor, director of International Clinical Center of Reproduction "PERSONA", Almaty, Kazakhstan ORCID: 0000-0002-4792-5380

R.K. VALIEV

PhD, Head of Reproductology Department of International Clinical Center of Reproduction "PERSONA", Almaty, Kazakhstan ORCID: 0000-0003-2526-4291

A.N. RYBINA reproductologist of International Clinical Center of Reproduction "PERSONA", Almaty, Kazakhstan ORCID: 0000-0002-9368-6683

K.T. NIGMETOVA embryologist of International Clinical Center of Reproduction "PERSONA",

Almaty, Kazakhstan

ORCID: 0000-0003-1643-7293

SH.K. KARIBAYEVA

$\mathrm{PhD}$, reproductologist of International Clinical Center of Reproduction "PERSONA", Almaty, Kazakhstan ORCID: 0000-0001-5691-8652

Contacts:

Vyacheslav N. Lokshin

International Clinical Center of Reproduction "PERSONA" Utepova 32A

050060 Almaty, Kazakhstan

Tel. : 7 (727) 3827777

email:v_lokshin@persona-ivf.kz 


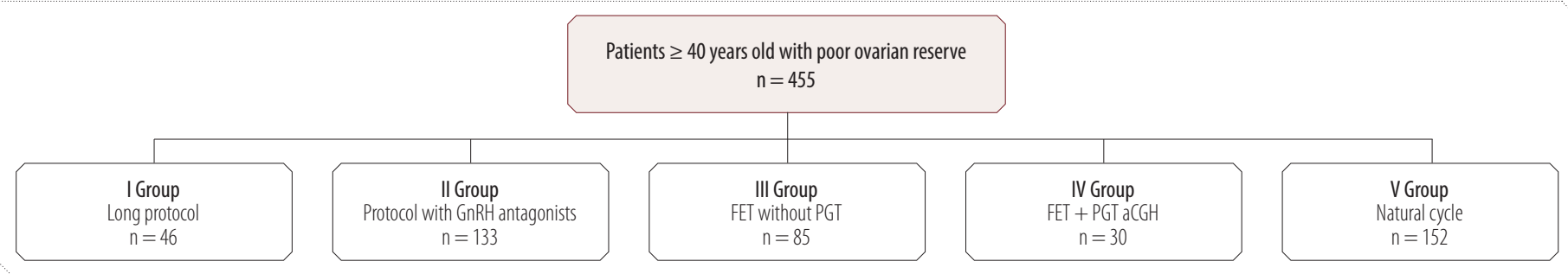

Figure 1. Characteristics of the studied groups

PGT - preimplantation genetic testing; FET - frozen embryo; GnRH - gonadotropin-releasing hormone; aCGH - array comparative genome hybridization

uation system. Auxiliary laser hatching for 3 days was carried out for all embryos on the Octax-Octax Navi Lase installation. For trophectoderm biopsy, blastocysts of at least 2BA quality were selected according to Gardner's classification. A biopsy of a trophectoderm technique of a fence not less than 2-3 kernels by the Flick or Pulling methodwas performed.

The data obtained in the study were subjected to statistical processing by the method of variation statistics using the free version of the EPI Info program. The arithmetic mean (M) and standard deviation $( \pm S D$ ) were calculated for quantitative indicators, data were presented as $\mathrm{M} \pm \mathrm{SD}$. Two-sided Student t-test was used when comparing averages. Absolute ( $n$ ) and relative (\%) values describe qualitative variables. The $X^{2}$ test was used to compare frequencies and quality variables; $p<0.05$ was considered significant.

We evaluated pregnancy rate (PR) per embryo transferand live birth rate (LBR) per embryo transferas IVF outcomes.

The study received ethical approval from the Local Ethical Committee of the International clinical center of reproductology "PERSONA".

\section{RESULTS OF THE STUDY}

There was no statistically significant difference in the age, Anti-Müllerian hormone $(\mathrm{AMH})$ level and duration of infertility between the groups. Table 1 presents data of the protocols of patients with poor ovarian response in fresh cycles.

Despite different protocols of ovarian stimulation there was no statistically significant difference in pregnancy rate in fresh cycles. At the same time, cancellation of transfer significantly higher was observed in natural cycles, $\mathrm{p}<0.001$.

When we compared fresh and frozen embryo transfers, we identified that PR and LBR were statistically significant higher in freeze embryo transfer group $29 \%$ and $12.1 \%$ vs $13.3 \%$ and $5.5 \%$ respectively $(p<0.001$ and $p=0.040$ ) (Table 2).

There was no statistically significant difference in the age, AMH level and duration of infertility between the FET groups. When we analyzed the group of frozen transfers, it was found that during the transfer of the embryo unexamined and after PGS the pregnancy rate did not differ $(29.4 \%$ vs $28.2 \%, p>0.05$ ), but LBR was statistically significant higher after euploid embryo transfer (8.2\% without PGS vs $20.5 \%$ after PGS, $p=0.028$ ) (Table 3 ).

\section{DISCUSSION}

The reason for this study was an increased number of patients with poor ovarian reserve from 20 to $38 \%$ of the total number of all initiated IVF/ ICSI cycles over the past 2 years. Our specialists, as well as reproductologists from other countries, faced with the imperfection of the classification methodology of patients of this group and, as a result, the lack of systematic approaches to their management in ART programs.

The results of our study showed that the transfer of fresh embryos did not increase the pregnancy rate and did

Table 1. Characteristics of fresh embryo transfers in POR patients

\begin{tabular}{|c|c|c|c|c|}
\hline & $\begin{array}{l}\text { Long protocol, } \\
\text { I Group } \\
(n=46)\end{array}$ & $\begin{array}{l}\text { Protocol antiGnRH, } \\
\text { II Group } \\
(n=133)\end{array}$ & $\begin{array}{c}\text { Natural cycle, } \\
\text { V Group } \\
(n=152)\end{array}$ & $p, x^{2}$ \\
\hline Mean age, years* & $42.08 \pm 2.45$ & $42.41 \pm 2.65$ & $42.4 \pm 2.89$ & $p>0.05$ \\
\hline Mean $\mathrm{AMH}^{*}, \mathrm{ng} / \mathrm{ml}$ & $0.94 \pm 0.26$ & $0.73 \pm 0.35$ & $0.4 \pm 0.27$ & $p>0.05$ \\
\hline$P R^{* *}$ & $1(3.6 \%)$ & $14(18 \%)$ & $2(9.1 \%)$ & $\begin{array}{l}x^{2}=4.103 \\
p=0.129\end{array}$ \\
\hline Cancel of embryo transfer** & $18(39.1 \%)$ & $55(41,3 \%)$ & $130(85.5 \%)$ & $\begin{array}{c}x^{2}=69.460 \\
p<0.001\end{array}$ \\
\hline$L B R^{* *}$ & 0 & $7(9 \%)$ & & $\mathrm{NaN}$ \\
\hline
\end{tabular}

* means and SD are presented

** absolute numbers and percentages are presented

Table 2. Comparative characteristics of embryo transfers in POR patients

\begin{tabular}{|c|c|c|c|}
\hline & $\begin{array}{c}\text { Fresh embryo transfer } \\
(n=128)\end{array}$ & $\begin{array}{c}\text { Freeze embryo transfer } \\
(n=115)\end{array}$ & $p, X^{2}$ \\
\hline $\mathrm{PR}^{*}$ & $17(13.3 \%)$ & $36(29 \%)$ & $\begin{array}{c}X^{2}=11.538 \\
p<0.001\end{array}$ \\
\hline $\mathrm{LBR}^{*}$ & $7(5.5 \%)$ & $15(12.1 \%)$ & $\begin{array}{r}X^{2}=4.221 \\
p=0.040\end{array}$ \\
\hline
\end{tabular}

* absolute numbers and percentages are presented per embryo transfer

Table 3. Characteristics of freeze embryo transfersin POR patients

\begin{tabular}{|c|c|c|c|}
\hline & $\begin{array}{c}\text { FET } \\
\text { III Group }(n=85)\end{array}$ & $\begin{array}{c}\text { FET+CGH } \\
\text { IV Group }(n=30)\end{array}$ & p \\
\hline Mean age, years* & $42.35 \pm 2.38$ & $41.78 \pm 1.89$ & $p>0.05$ \\
\hline Mean AMH*, ng/ml & $0.52 \pm 0.23$ & $0.70 \pm 0.12$ & $p>0.05$ \\
\hline PR $^{* *}$ & $25(29.4 \%)$ & $11(28.2 \%)$ & $p>0.05$ \\
\hline LBR $^{* *}$ & $7(8.2 \%)$ & $8(20.5 \%)$ & $p=0.028$ \\
\hline
\end{tabular}

* means and SD are presented

** absolute numbers and percentages are presented 
not depend on the stimulation protocol. Natural cycles were associated with a high percentage of transfer cancellation due to the absence embryos suitable for transfer. There was no LBR in fresh embryos transfer in natural cycles.

The PR and LBR during the transfer of cryopreserved-thawed embryos, regardless of ploidy, were significantly higher than in fresh cycles.

Live birth rates were obtained by transferring cryopreserved-thawed euploid embryos examined by aCGH.

Thus, the most effective approach in patients with a poor ovarian response was cycle segmentation, cryopreservation of embryos, PGS and transfer of euploid embryo, which is consistent with published data [24].

In this category of patients, the accumulation of embryos and cumulative repeated cycles are relevant. However, the effectiveness and economic feasibility of funded programs requires further research.

The question of how to calculate the results remains open: according to ICMART (Committee for Monitoring Assisted Reproductive Technology) criteria [25] or only for the embryo transfer/initiated cycle?

\section{REFERENCES/ЛITEPATYPA}

1. Lokshin, V., Valiev, R., Rybina, A., Zaichenko, K.

"'Poor responders' - modern ideas, principles of management in art programs. review." Bulletin of National Academy of Sciences of the Republic of Kazakhstan 2.378 (2019): 177-88. DOI: 10.32014/2019.2518-1467.54

2. Orazov, M.R., Radzinsky, V.Y. Khamoshina, M.B., et al. "Gonadotropin-releasing hormone agonists and antagonists: influence on neuroangiogenesis and apoptosis in eutopic endometrium in a therapy for recurrering endometriosis genitalis externa-associated pelvic pain in patients." Bulletin of National Academy of Sciences of Republic of Kazakhstan 6.376 (2018): 19-33. ISSN 1991-3494. D0I: 10.32014/2018.2518-1467

3. Streuli, I., de Ziegler, D., Gayet, V., et al.

"In women with endometriosis anti-Müllerian hormone levels are decreased only in those with previous endometrioma surgery." Human Reproduction 27.11 (2012): 3294-303.

4. Raffi, F., Metwally, M., Amer, S.

"The impact of excision of ovarian endometrioma on ovarian reserve: a systematic review and meta-analysis."The Journal of Clinical Endocrinology \& Metabolism 97.9 (2012): 3146-54.

5. Rienzi, L., Cobo, A., Paffoni, A., et al.

"Consistent and predictable delivery rates after oocyte vitrification: an observational longitudinal cohort multicentric study." Human Reproduction 27.6 (2012): 1606-12.

6. Streuli, I., de Ziegler, D., Gayet, V., et al.

"In women with endometriosis anti-Müllerian hormone levels are decreased only in those with previous endometrioma surgery," Human Reproduction, vol. 27, no. 11, pp. 3294-3303, 2012.

7. de Vos, M., Devroey, P., Fauser, B.C.J.M.

"Primary ovarian insufficiency."The Lancet 376.9744 (2010): 911-21.

8. Soto, N., Iñiguez, G., López, P., et al.

"Anti-Müllerian hormone and inhibin B levels as markers

of premature ovarian aging and transition to menopause in type 1 diabetes mellitus." Human Reproduction 24.11 (2009): 2838-44.

\section{CONCLUSIONS}

The most effective approach in patients with a poor ovarian response was cycle segmentation, cryopreservation of embryOS, PGS and transfer of an euploid embryo. This category of patients requires a personalized approach to the treatment of infertility. The choice of protocol must be carried out with the full voluntary and informed consent of the patient, depending on their desires and capabilities, including financial. It is required to calculate the medical and economic efficiency of funded programs in Kazakhstan. Conducting randomized clinical trials on a larger number of patients in order to assess the dependence of the effectiveness of IVF/ICSI on the quality and quantity of transferred embryos after thawing, hormone levels can help answer unresolved questions.

\section{Conflict of interest}

There is no conflict of interest in any author.
9. Chang, H.-H., Chen, M.-J., Lu, M.-Y., et al.

"Iron overload is associated with low anti-müllerian hormone in women with transfusion-dependent $\beta$-thalassaemia." British Journal of Obstetrics and Gynaecology 118.7 (2011): 825-31. 10. Tropeano, G., Di Stasi, C., Amoroso, S., et al.

"Long-term effects of uterine fibroid embolization on ovarian reserve: a prospective cohort study." Fertility and Sterility 94.6 (2010): 2296-300.

11. Liu, K., Case, A.; Reproductive Endocrinology and Infertility Committee, Family Physicians Advisory Committee, MaternalFetal Medicine Committee, Executive and Council of the Society of Obstetricians.

"Advanced reproductive age and fertility." JOGC 33.11 (2011): 1165-75.

12. Sunkara, S.K., Rittenberg, V., Raine-Fenning, N., et al. "Association between the number of eggs and live birth in IVF treatment: an analysis of 400135 treatment cycles." Human Reproduction 26.7 (2011): 1768-74. D0l: 10.1093/humrep/ der106

13. Ferraretti, A.P., et al.

"ESHRE consensus on the definition of 'poor response' to ovarian stimulation for in vitro fertilization: the Bologna criteria."Hum Reprod 26.7 (2011): 1616-24.

14. Polyzos, N.P., Nwoye, M., Corona, R., et al.

"Live birth rates in Bologna poor responders treated with ovarian stimulation for IVF/ICSI." Reproductive BioMedicine Online 28.4 (2014): 469-74.

15. Polyzos, N.P., Devos, M., Humaidan, P., et al. "Corifollitropinalfa followed by rFSH in a GnRH antagonist protocol for poor ovarian responder patients: an observational pilot study." Fertility and Sterility 99.2 (2013): 422-6.

16. Polyzos, N.P., Devroey, P.

"A systematic review of randomized trials for the treatment of poor ovarian responders: is there any light at the end of the tunnel?" Fertility and Sterility 96.5 (2011): 1058.e7-1061.e7.

17. Al-Azemi, M., Killick, S.R., Duffy, S., et al.

"Multi-marker assessment of ovarian reserve predicts oocyte yield after ovulation induction." Human Reproduction 26.2 (2011): 414-22.

18. Frydman, R

"Poor responders: still a problem." Fertil Steril 96.5 (2011):

1057. D0l: 10.1016/j.fertnstert.2011.09.051.2011
19. Kolibianakis, E.M., Venetis, C.A., Diedrich, K., et al. "Addition of growth hormone to gonadotrophins in ovarian stimulation of poor responders treated by in-vitro fertilization: a systematic review and meta-analysis." Human Reproduction Update 15.6 (2009): 613-22.

20. Liu, K., Case, A.; Reproductive Endocrinology and Infertility Committee, Family Physicians Advisory Committee, MaternalFetal Medicine Committee, Executive and Council of the Society of Obstetricians.

"Advanced reproductive age and fertility." JOGC 33.11 (2011): 1165-75.

21. Pandian, Z., McTavish, A.R., Aucott, L., et al. "Interventions for 'poor responders' to controlled ovarian hyper stimulation (COH) in in vitro fertilization (IVF)." Cochrane Database Syst Rev 1 (2010): (D004379. D0l: 10.1002/14651858.CD004379.pub3

22. Reynolds, K.A., Omurtag, K.R., Jimenez, P.T., et al. "Cycle cancellation and pregnancy after luteal estradiol priming in women defined as poor responders: a systematic review and meta-analysis." Human Reproduction 28.11 (2013): 2981-9.

23. Polyzos, N.P., Blockeel, C., Verpoest, W., et al. "Live birth rates following natural cycle IVF in women with poor ovarian response according to the Bologna criteria." Human Reproduction 27.12 (2012): 3481-6.

24. Ubaldi, F., Anniballo, R., Romano, S., et al.

"Cumulative ongoing pregnancy rate achieved with oocyte vitrification and cleavage stage transfer without embryo selection in a standard infertility program." Human Reproduction 25.5 (2010): 1199-1205.

25. Vaiarelli, A., Cimadomo, D., Trabucco, E., et al. "Double Stimulation in the Same Ovarian Cycle (DuoStim) to Maximize the Number of Oocytes Retrieved From Poor Prognosis Patients: A Multicenter Experience and SWOT Analysis." Front Endocrinol (Lausanne) 9 (2018): 317. D01: 10.3389/fend0.2018.00317

26. Zegers-Hochschild, F., Adamson, G.D., Dyer, S., et al. "The International Glossary on Infertility and Fertility Care, 2017." Fertil Steril 108.3 (2017): 393-406. D0l: 10.1016/j. fertnstert.2017.06.005 


\section{OUTCOMES IN POOR RESPONDERS TREATED WITH IN VITROFERTILIZATION/INTRACYTOPLASMIC SPERM INJECTION ACCORDING TO BOLOGNA CRITERIA}

V.N. Lokshin, MD, PhD, professor, director of International Clinical Center of Reproduction "PERSONA", Almaty, Kazakhstan

R.K. Valiev, PhD, Head of Reproductology Department of International Clinical Center of Reproduction"PERSONA", Almaty, Kazakhstan

A.N. Rybina, reproductologist of International Clinical Center of Reproduction "PERSONA", Almaty, Kazakhstan

K.T. Nigmetova, embryologist of International Clinical Center of Reproduction "PERSONA", Almaty, Kazakhstan

Sh.K. Karibayeva, PhD, reproductologist of International Clinical Center of Reproduction "PERSONA", Almaty, Kazakhstan

Purpose of the study was to evaluate the effectiveness of various approaches of artificial reproductive technologies (ART) in advanced maternal age patients with poor ovarian response (POR). Materials and methods. This is retrospective cohort study of 455 patients with POR who have undergone an IVF and embryo transfer program at from June 2016 to June 2018 . Researchers evaluated pregnancy rate (PR) per embryo transferand live birth rate (LBR) per embryo transferas in vitro fertilization (IVF) outcomes. The patients fulfilled Bologna criteria were divided into 5 groups: Iong protocol, ant-gonadotropin-releasing hormone protocol, freeze embryos transfer without preimplantation genetic diagnostic (PGS), freeze embryos transfer with PGS, natural cycle. Results. There was no statistically significant difference in the age, Anti-Müllerian hormone level and duration of infertility between the groups. Despite different protocols of ovarian stimulation, there was no statistically significant difference in pregnancy rate in fresh cycles. At the same time, cancellation of transfer was significantly higher observed in natural cycles $(p<0.001)$. PR and LBR were statistically significant higher in freeze embryo transfer group $29 \%$ and $12.1 \%$ vs $13.3 \%$ and $5,5 \%$ respectively $(p<0.001$ and $p=0.040$ ). During the transfer of the embryo unexamined by PGS and after PGS the pregnancy rate did not differ ( $29.4 \%$ vs $28.2 \%, p<0.05)$, but LBR was statistically significant higher after euploid embryo transfer ( $8.2 \%$ without PGS vs $20.5 \%$ after $P G S, p=0.028)$.

Conclusion. The most effective approach in patients with a poor ovarian response was cycle segmentation, cryopreservation of embryos, PGS and transfer of an euploid embryo. This category of patients requires a personalized approach to the treatment of infertility. The choice of protocol in ART program must be carried out with the full voluntary and informed consent of the patient, depending on their desires and capabilities, including financial.

Keywords: infertility, poor ovarian response, in vitro fertilization.

\section{ИСХОДЫ ПРОГРАММ ЭКСТРАКОРПОРАЛЬНОГО ОПЛОДОТВОРЕНИЯ/ИНТРАЦИТОПЛАЗМАТИЧЕСКОЙ ИНЪЕКЦИИ СПЕРМАТОЗОИДА УПАЦИЕНТОК С НИЗКИМ ОВАРИАЛЬНЫМ ОТВЕТОМ СОГЛАСНО БОЛОНСКИМ КРИТЕРИЯМ}

В.Н. Локшин, д. мед. н., профессор, директор Международного клинического центра репродуктологии PERSONA, Алматы, Казахстан

P.К. Валиев, К. мед. Н., главный врач Международного клинического центра репродуктологии PERSONA, Алматы, Казахстан

A.Н. Рыбина, репродуктолог Международного клинического центра репродуктологии PERSONA, Алматы, Казахстан

K.T. Нигметова, эмбриолог Международного клинического центра репродуктологии PERSONA, Алматы, Казахстан

Ш.К. Карибаева, К. мед. н., директор по развитию Международного клинического центра репродуктологии PERSONA, Алматы, Казахстан

Целью исследования стала оценка эффективности различных протоколов вспомогательных репродуктивных технологий (ВРТ) у пациенток старшего репродуктивного возраста с низким овариальным ответом.

Материалы и методы исследования. Проведено ретроспективное когортное исследование, в которое были включены 455 пациенток с бесплодием, удовлетворявших Болонским критериям бедного ответа яичников и проходивших лечение методом экстракорпорального оплодотворения (ЭКО)/интрацитоплазматической инъекции сперматозоида (ИКСИ) с июня 2016 по июнь 2018 г.

Исследователи оценивали частоту беременности на один перенос эмбриона и частоту живорождений на один перенос эмбриона при ЭКО. Пациентки, соответствующие Болонским критериям, были разделены на 5 групп: группа длинного протокола, протокол с антагонистами гонадотропин-рилизинг-гормона, протокол размороженных эмбрионов без преимплантационной генетической диагностики (ПГС), протокол переноса размороженных эмбрионов с ПГС, естественные циклы.

Результаты. Не выявлено статистически значимой разницы в частоте наступления беременности и живорождения в зависимости от выбранного протокола стимуляции яичников при переносе в свежем цикле. Установлено, что отмена переноса достоверно чаще отмечалась в естественных циклах ( $<<0,001)$. При анализе результативности свежих и криопереносов выявлено, что частота беременности и частота живорождения статистически отличалась: 29\% и 12,1\% против 13,3\% и 5,5\% со0тветственно (p <0,001 и p =0,040). В группе криопереносов частота родов была достоверно выше при переносе эуплоидного эмбриона (8,2\% без ПГС против 20,5\% после ПГС, $p=0,028)$, тогда как частота беременности статистически не отличалась.

Выводы. Наиболее результативным подходом у пациенток с бедным ответом яичников стала сегментация цикла, криоконсервация эмбрионов, проведение ПГС и перенос эуплоидного эмбриона. Данная категория пациенток требует максимально персонифицированного подхода при лечении бесплодия. Выбор протокола стимуляции овуляции в программе ВРТ необходимо проводить совместно с пациентками в зависимости от их ожиданий и возможностей, в том числе финансовых.

Ключевые слова: бесплодие, бедный ответ яичников, экстракорпоральное оплодотворение.

\section{РЕЗУЛЬТАТИ ПРОГРАМ ЕКСТРАКОРПОРАЛЬНОГО ЗАПЛІДНЕННЯ/ІНТРАЦИТОПЛАЗМАТИЧНОЇ ІН'ЕКЦІЇ СПЕРМАТОЗОЇДА В ПАЦІЕНТОК ІЗ НИЗЬКОЮ ОВАРІАЛЬНОЮ ВІДПОВІДДЮ ЗГІДНО}

B.Н. Локшин, д. мед. н., професор, директор Міжнародного клінічного центру репродуктології PERSONA, Алмати, Казахстан

P.К. Валієв, к. мед. н., головний лікар Міжнародного клінічного центру репродуктології PERSONA, Алмати, Казахстан

A.М. Рибіна, репродуктолог Міжнародного клінічного центру репродуктології PERSONA, Алмати, Казахстан

K.T. Нігметова, ембріолог Міжнародного клінічного центру репродуктології PERSONA, Алмати, Казахстан

Ш.К. Карібаєва, К. мед. н., директор з розвитку Міжнародного клінічного центру репродуктологї̈ PERSONA, Алмати, Казахстан

Метою дослідження була оцінка ефективності різних протоколів допоміжних репродуктивних технологій (ДРТ) у пацієнток старшого репродуктивного віку з низькою оваріальною відповіддю.

Матеріали і методи дослідження. Проведено ретроспективне когортне дослідження, в яке були включені 455 пацієнток з безпліддям, котрі задовольняли Болонським критеріям бідної відповіді яєчників і проходили лікування методом екстракорпорального запліднення (ЕКЗ)/інтрацитоплазматичної ін'єкції сперматозоїда (IКСІ) 3 червня 2016 до червня 2018 р. Дослідники оцінювали частоту вагітності на одне перенесення ембріона і частоту живонароджень на одне перенесення ембріона при ЕКЗ. Пацієнтки, які відповідали Болонським критеріям, були розділені на 5 груп: група довгого протоколу, протокол із антагоністами гонадотропін-рилізинг-гормону, протокол розморожених ембріонів без преімплантаційної генетичної діагностики (ПГС), протокол перенесення розморожених ембріонів із ПГС, природні цикли.

Результати. Не виявлено статистично значущої різниці в частоті настання вагітності і живонародження в залежності від обраного протоколу стимуляції яєчників при перенесенні в свіжому циклі. Встановлено, що відміна перенесення достовірно частіше відзначалася в природних циклах ( $<<0,001)$. При аналізі результативності свіжих і кріоперенесень виявлено, що частота вагітності та частота живонароджень статистично відрізнялася: $29 \%$ i 12,1\% проти 13,3\% і 5,5\% відповідно (p < 0,001 і р = 0,040). У групі кріоперенесень частота пологів була достовірно вищою при перенесенні еуплоїдного ембріона (8,2\% без ПГС проти 20,5\% після ПГС, p=0,028), тоді як частота вагітності статистично не відрізнялася. Висновки. Найбільш результативним підходом у пацієнток із бідною відповіддю яєчників виявилася сегментація циклу, кріоконсервація ембріонів, проведення ПГС і перенесення еуплоїдного ембріона. Дана категорія пацієнток вимагає максимально персоніфікованого підходу при лікуванні безпліддя. Вибір протоколу стимуляції овуляції в програмі ДРТ необхідно проводити спільно з пацієнтками в залежності від їх очікувань і можливостей, в тому числі фінансових.

Ключові слова: безпліддя, бідна відповідь яєчників, екстракорпоральне запліднення. 